\title{
The contribution of historic urban spaces in influencing the character of George Town UNESCO World Heritage Site, Malaysia
}

\author{
C. A. Rohayah, S. Shuhana \& B. S. Ahmad \\ Universiti Teknologi Malaysia, Malaysia
}

\begin{abstract}
This paper examines the significance of the historic urban spaces in influencing the character of George Town UNESCO World Heritage Site (WHS) by analyzing the perception of the residents towards the character of the heritage sites. George Town was the first British port city recognized as having a unique architectural and cultural townscape that was inscribed together with Malacca as a UNESCO World Heritage Site in 2008. The multi-cultural character influences of Asia and Europe have created tangible and intangible elements that contribute to the character of the historic urban spaces. The significance of the historic buildings with unique its architecture and the urban pattern derived through their juxtaposition on the site has created unique spaces that characterized the George Town WHS. These rows of pre-war historic buildings enclosed the areas and create the planned or incidental urban spaces, which divided the area into several significant streets or spaces. The names of the street depict the historical significance of the area having a close association with the existence of different groups of the community. The findings suggest that the historic urban spaces play an important role in influencing the character of the WHS sites.

Keywords: historic urban space, world heritage site, character, townscape.
\end{abstract}

\section{Introduction}

George Town was the oldest British colonial town in South East Asia which represents the early development of British period at the end of the 18th C. The names of the street depict the historical significance of the area. Each of the streets portrays character the existence of the community with different historical background such as Acheh Street, Farquhar Street, Armenian Street 
and Pitt Street (Jalan Masjid Kapitan Keling) known for their Muslim/Indian Muslim Community; therefore where Bishop Street, Church Street and Buckingham Street are associated with Christianity, whilst Little India denotes the Indian community and China Street is the replication of the Chinese community.

The existence of these communities within the case study area had been influenced by civilization exchanges as a result of George Town's role as a trading port that brought people from various backgrounds and culture. The trade activities within the urban spaces, which are based on ethnicity had reinforced and formed the strong character of George Town WHS. This strong character is consistent with the inscription of the case study area in the statement of Outstanding Universal Value (OUV), Criterion (ii) represents the exceptional example of multi-cultural trading town that shows different stages of development and the successive changes over a long span of time and thus complementary [1].

\section{Methodology}

The methodology is a case study using mixed method, where both qualitative and quantitative approaches were adopted. The literature review, visual survey and a questionnaire survey of 405 respondents was conducted to assess the residents' perception of the historic urban spaces in giving the character to the WHS. The majority of the respondents' age is between 21 years old and above with higher participation received from the male residents. The three main ethnic groups of the case study: Chinese, Malay (including India Muslim and Jawi Peranakan) and Indian were represented in the survey whereby the Chinese represented the ethnic majority. The respondents' age group are ranging from 31 years and above with an almost extreme gap of distribution between the Chinese (54.3\%), Malay (19\%) and Indian (24.2\%) and Others (2.5\%). The data provided from the survey shows that the majority of the participants (64\%) are locals who are the residents in the case study area for six years and above.

\section{Historic urban spaces}

Rossa in Gonvales [2] refers to urban as everything that are related to the city such as the relations that people establishes with others and with its surrounding environment. An urban space is the result of the spatial organization of the buildings and creates spaces within the town and cities [3]. The uniqueness of the town is portrayed by its space organization, formation of streets, buildings grouped, traditions (local and national), level of changes, important and prominent buildings and landscape spaces $[3,4]$. The geographical setting has a strong influence on the identity of place [3,5-7]. This will be related to the location and positioning of the towns or cities according to landform, landscape, water bodies and topography [3, 7]. This paper will discuss on Krier [8] and Shuhana [3] works, which suggested that the two main elements in types of the urban spaces are the street and the square $[3,8]$. There are several possible 
explanations for the above literature reviews that historic urban space shall be defined as a space with dominant activities (with relationships between people) that created and defined the character of place by integrating the components and elements of the spaces / within spaces. This invokes significant value of place and synchronizes it with the current contemporary use, components and elements.

\subsection{Square}

Padang Kota Lama and Esplanades, which are located at the edge of the Straits of Malacca, are classified as a square based on Krier's [8] definition. It is an area surrounded by a group of buildings and the open space, which becomes the most important element in the city [3] functions as a meeting place and where the major colonial civic buildings are located. These two places also function as a node by Lynch [9] and as Moughtin's [8] definition of a center, they become places where people tend to gather and interact. Moughtin [10] in Shuhana [3] categorized the square into two types: its function and its form. The function relates to the activities and the ability of the square to support the designated activities as in an example, a setting for civic buildings, meeting places, ceremonial occasions and others. On the other hand, the form of the square is based on the composition and the degree of enclosure.

The Esplanades or Padang Kota is located at the strategic part of the historic Light Street (Lebuh Light). The enclosed public open area with green field and recreation facilities becomes a gathering area for locals and tourists. According to the Oxford dictionary, the definition of the esplanade (from the Latin word 'esplanare', to make level) is “ a long, open, level area, typically beside the sea, along which people may walk with pleasure”. During the colonial era, these two areas were the important node for the social activities for the locals. Historically, this Esplanade was a ground practice for the military, as well as the British public using it for the sports (soccer, cricket, lawn bowling and etc.). The Filipino groups also used to perform while serenading the people out on the stroll. Meanwhile, the magicians also used the space to entertain the pilgrims leaving for Haj here. The annual festival of Pesta Pulau Pinang (Penang Festival) used to be held here before moving to its permanent location in another part of the island.

Currently, this historic public space hosts many activities such as leisure walks tournament, major sports events, concerts, assemblies, the new year celebrations, parades and other community events. Recently, new activities were created by local authorities such as a public talk, which is held at the "Dataran Pidato" (Speaker's Square) at the Esplanade/Padang. The local communities have the freedom to give a speech and assemble here. This place also becomes a node where people gather especially during the weekends and weekday afternoon besides being a tourist attraction for the historic area (Fort Cornwallis). The authority also provides a playground and food courts as a support to the other activities occurring in the place. Burke and Ewan [11] stated that the open space also contributes to the quality of life. These activities that occur at this 
historical Padang and Esplanades had contributed significantly towards the visual and sensory experience of the townscape [3].

The result of survey shows that a majority (65\%) of the respondents strongly agreed with the Esplanade and Padang Kota as being the most important nodes compared to KOMTAR, Weld Quay/Swettenham and Cruise Pier. The factors that respondents strongly agreed with the Esplanade and Padang Kota as being the best location for public nodes are because of their accessibility (70.5\%), activities of the area (58.7\%), interesting views and scenery (55.7\%), safety and comfortable (53\%) and memory of the place (53.5\%). The responses from the survey suggested that the location of the historic Padang Kota and Esplanade are important in influencing the accessibility of the place where, in an urban context, the nodes should be identified and supported by the activities held at this place as a gathering spot. Nodes according to Lynch [9] are the strategic points or dominant feature in the city in which people can enter either as a street-hangout or enclosed square. Through the visual survey these areas are located in a strategic area, which are accessible to major public transportation (both water and land transports). Their location at the edge of the water, facing the South China Sea, contributes to the picturesque and interesting scenery of George Town and its surroundings. The Padang Kota Lama and Esplanade also have meanings that are associated with the historical development of George Town, being the first landed area of Captain Francis Light in 1786. The Esplanade and the Padang were designed and being used for recreational purposes surrounded with significant and important historical buildings such as Town Hall (1883); City Hall (opened in 1906); the monument of World War 1 such as Cenopath; there was also a spot where German ships (known as SMS Emden and Zhemchug) were sunk in 1914 during the Battle of Penang. In the 2nd World War, the bombs had destroyed the historical Penang Sport Cricket Club (located at the Padang) and two Victorian cast iron pavilions (the Vermont Memorial and Municipal Band Stand). The findings from the historical research shows that the Esplanade and Padang Kota was an important point for development and urban expansion of George Town, from the location of administrative and settlement of the Europeans during the colonial period and transforming into recreation areas / open public spaces today. These findings support the idea that the Esplanade / Padang Kota was as an open field that are the main nodes for the recreational and social center of George Town WHS.

\subsection{Street}

The streets and its streetscape elements are important in defining the character of urban areas [3, 12, 13]] where most of the town's residents live within [3]. The street also functions as a place, whose qualities must be enclosed similar to a square $[3,10]$. Historically, George Town street pattern was laid out by Francis Light based on the colonial practice of rectangular blocks of 30-40 feet wide street [14], creating an irregular gridiron street pattern, bordered by Light Street, Beach Street, Chulia Street and Pitt Street (Jalan Masjid Kapitan Keling). Kitamura and Jamilah [15] discussed on Hassan [16] about the legacies of the British colonial rule in George Town, Penang, Malaysia and its influence on 
the city layout and transport access. The British had adopted the concept of gridiron layout in George Town's planning similar to the model of the primary Roman colonies, which also adopted in America and Australasia. The Romans had copied from the Greek town planners and had upgraded the pattern by adding two primary streets, which were referred to as 'Cardo' and 'Decumanus'. Historically, Beach Street served as a primary access (“Cardo”) but after the land reclamation in 1881, the Weld Quay became the primary "Cardo" access to the George Town inner city. Meanwhile, Light Street has been established as the "decumancus", i.e. the primary East-West transport access. As a multi-cultural entrepot, Francis Light also proposed that "each race has a right to preserve its civil and religious peculiarities” [17, 18]. There was no formal segregation imposed by the British in the urban spaces of the case study area [18] but the British allowed for the local residents to build the divided zones based on their background and beliefs [16]. However, the zones in urban context were bounded by Lynch's [9] term as edges i.e. boundaries between different types of spaces. George Town was then divided into three zones during its early development: Defensive Zone, Administrative Zone and Settlement Zone) and were then created eight primary zones (under divide and rule concept by the British). The zones were; the British Administration and Settlement, Indian Hindu settlement, Port and Financial settlement, Indian Muslim settlement, Malay settlement, Chinese settlement (east), Chinese settlement (north) and Commercial area and the market, where the settlements were segregated with street borders.

Each of the streets portrays the identity of a community with different historical background such as Acheh Street, Farquhar Street, Armenian Street and Pitt Street (Jalan Masjid Kapitan Keling) for Muslim/Indian Muslim Community, Bishop Street, Church Street and Buckingham Street convey Christianity, Little India denotes for India community and China Street replication of the Chinese community. Through observation and analysis of government documentations, the current situation of the case study has been transformed and segregated according to the socio-cultural topography. The segregation is based on the distribution of a cultural enclave and defined by building, spaces and paths (refer Figure 1).

The survey findings convey that majority of the respondents (55.3\%) choose Lebuh Light (formerly known as Light Street) as the street with the most beautiful view followed by Beach Street/Lebuh Pantai, Jalan Masjid Kapitan Keling and Lebuh Leith. Table 1 shows the chi square test that the age group, race group and duration of stay in George Town towards the importance of Light Street to the respondents. The result shows that there is a strong relationship between the age group, race group and length of stay and respondents' perception on the importance of Light Street as the p value is lower than .050 $(p=.000)$. This result suggests that Light Street is the most important and memorable street in George Town WHS. This finding also collaborates with the previous study and arguments from Tuan [19], Appleyard [20], Lowenthal [21], Rapport [22] and Wan Hashimah [23] suggest that there is an influence by the 


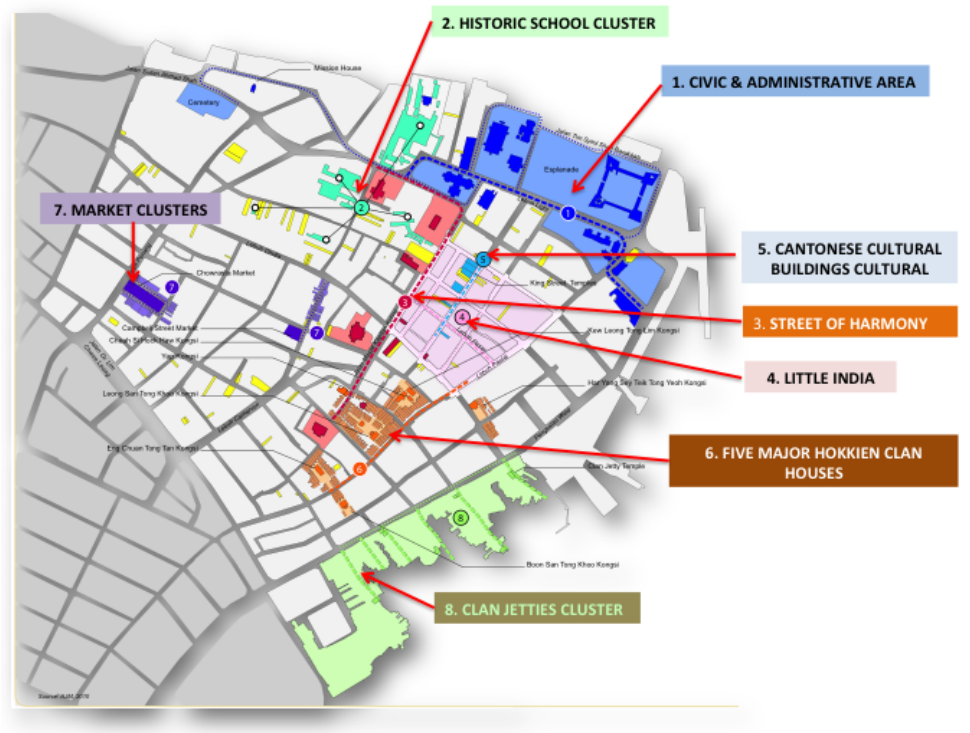

Figure 1: The socio-cultural typology (source: adapted from George Town Special Area Plan, 2011).

different socio-cultural groups on the perceptions of the people towards their townscape.

The reason for the respondents' selection of Light Street as an important the street in the area is because of the presence of historical buildings with interesting architectural design and decorations fronting the street of the area (65.8\%). While another $31.3 \%$ of the respondents' reason is due to the rows of the historic buildings along the street. From the visual survey, Light Street has a long vista, which was enclosed by the historical buildings and rows of trees along the street. Light Street (Lebuh Light) was a settlement area, named after Captain Francis Light. The early development of this street was the location of government buildings and Europeans' residences. Strong evidence of the significant historical buildings was found during the visual survey and supported by historical research. The historical buildings located on Light Street are the Fort Cornwallis, the Council buildings and State Assembly Hall, Convent Light Street School, Eastern and Oriental Hotel, The Supreme Court Buildings, Logan Memorial and the Government House. This view is supported by Shuhana [3] who postulates that the building line along the street has a significant effect in creating the character of the urban space. Historical research and authority survey also show that there are more than 1700 historic buildings located within the main streets of the core zones of the case study area.

The noticeable elements or landmarks that are recognized by the respondents in this street is the water features (58.8\%) at the Queen Victoria Clock Tower (48.1\%), which are also situated at the intersection of Light Street (Lebuh 
Light), Beach Street (Lebuh Pantai) and King Edward Place (Pesara King Edward). The clock tower is designed with Moorish style architecture to commemorate Queen Victoria's Diamond Jubilee. What is interesting is that the similar towers were built in Britain such as Maidenhead Diamond Jubilee Clock Tower and Thornford Clock Tower. The authority added water features and steel sculpture of betel nut at the location of the historic clock tower. Landmark is the point of reference, which was defined by physical objects in the urban areas [8]. These findings support the ideas that from the historical research and visual survey a few dominant objects such as historical buildings were identified as a landmark in the case study such as the Kapitan Keling Mosque, Acheen St, Mosque, Fort Cornwallis and etc. The dominant building during the colonial era with significant character and most revered buildings in historical journals, paintings and photographs was the FMS Building. These findings support previous definition by Lynch [9] that the landmark shall be seen from many distances and angles and symbolized a constant direction. Hasanuddin [24] defined the landmark as dominant landscape features that impress people's perception towards their environment.

Through the visual survey, George Town WHS has different sizes, length and width of the streets, which influence the activities of the inside and outside of the buildings; and ethnic background of the community. Recent evidence from visual surveys conveys that many of the streets in the case study still remain historically intact. As in Figure 1 above, the Little India area accommodates the cluster of Indian cultural retail businesses, street stalls and settlement for Indian residents. The market cluster on Chowrasta Market and Campbell Street market and its surrounding areas such as Jalan Kuala Kangsar has turned into an open air street market in the morning creating additional activities within the street. Some of the area in the case study, namely Jalan Masjid Kapitan Keling is called the Street of Harmony, where the street becomes a setting for different religious and spiritual area (refer to Figure 1). This street holds different types of religious buildings or worship areas such as Islam, Christianity, Buddhism and Hinduism that create a sensory experience and influences the character of the place [3]. Vahid [25] stated that the urban space is part of the city, which is harmonious, continuous and enclosed containing social environment (relationship between people). Urban activities are the most important aspect of character element and content of urban space. These activities will create characters and spirit of place, components, specific elements and human activity. The social background of its multicultural heritage had influenced the names of the streets in the case study. The street was named according to its significant history, the leader or influential person during the era, activities and other socio-cultural factors. Most of the street was named during the colonial era and are still used by the locals.

\section{Conclusion}

In the urban context, character of urban spaces are associated with the character of a place as being unique, outstanding, dominant, recognizable, memorable, different and identifiable by the people $[4,8,26]$. The main elements in the 
urban spaces that create the character of the place are streets, square, buildings and activities, where the meanings and the role of these elements are based on the design, arrangement and detailing. These elements contribute in giving significant meaning towards the character of the case study. The significant contributions of street as historic urban spaces in influencing the character of George Town WHS shall be concluded that the establishment of the gridiron concept, which established the formal and informal layout of street design in George Town. The historic spaces, which had been segregated by multi-cultural ethnic background, give a significant impact to the townscape and influencing the identity of the place. Therefore, the activities, the physical character of the buildings and streetscape elements create the identity of the historic urban space. The significant historic buildings within the urban spaces with unique architecture are the most valued assets for George Town WHS.

\section{References}

[1] UNESCO, Melaka and George Town, Historic Cities of The Straits of Malacca, whc.unesco.org/en/list/1223

[2] Goncalves, A., Which Urban Plan For An Urban Heritage? An Overview Of Recent Portuguese Practice On Integrated Conservation. City \& Time. 3:2. pp 67-79, 2008.

[3] Shuhana, S., Townscape Revisited - Unravelling The Character of Historic Townscape In Malaysia. UTM Press: Malaysia, 2011.

[4] Shuhana, S., Identity of Place - Study of Kuantan Town Centre Malaysia. PhD Thesis. University of Nottingham, 1997.

[5] Tugnut, A and Robertson, Making Townscape - A Contextual Approach of the World Heritage Sites by emphasizing on the relationship between the spaces and the history of the sites. To Building In An Urban Setting. Mitchell: London, 1997.

[6] Goldsteen, J.B. and Elliot, C.D., Designing America - Creating Urban Identity, Van Nostrand Reinhold New York, 1994.

[7] Norberg-Schulz, C., Genius Loci - Towards A Phenomenology of Architecture, Rizolli International Publications: New York, 1980.

[8] Krier, R., Urban Space, Academy Edition: London, 1979.

[9] Lynch, K., The Image of The City, MIT Press: Cambridge, 1960.

[10] Moughtin, J., Urban Design - Street and Square. Butterworth-Heinemann: Oxford, 1992.

[11] Burke, J and Ewan, J., Sonoran, Preserve Master Plan For The Phoenix Sonoran Desert, City of Phoenix Parks, Recreational Library Department, 1999.

[12] Nasar, J.L., Perception Cognition and Evaluation of Urban Places in Human Behavioral and Environment - Advances In Theory and Research. Vol 10. In Public Places and Spaces. Altman, I and Zube, E.H. New York Plenum Press: New York, 1989.

[13] Shuhana, S, Ahmad, B.S and Rohayah, C.A, Urban Landscape Factors That Influenced The Character of George Town, Penang Unesco World Heritage 
Site. AcE-BS 2012 Bangkok, ASEAN Conference on EnvironmentBehaviour Studies, Bangkok Thailand. 16-18 July 2012. Procedia Social and Behavioral Sciences, 2012.

[14] Fels, P, Conserving The Shophouse City. The Penang Story - International Conference 18-21 April 2002, The City Bayview Hotel Penang Malaysia. Penang Heritage Trust and Star Publications, 2002.

[15] Kitamura, R and Jamilah, M., Rapid Motorization in Asian Cities: Urban Transport Infrastructure, Spatial Development and Travel Behavior. Transportation Vol 36 pp 269-274, 2009.

[16] Hassan, A.S., The British Colonial "Divide and Rule" concept - Its Influence To Transport Access In Inner City of George Town Penang. Transportation Vol 36, pp. 309-324, 2009.

[17] DeBernadi, J.E., Rites of Belonging - Memory, Modernity and Identity In A Malaysian Chinese Community. Standford University Press, 2004.

[18] Khoo, S.N, The Street of Harmony In George Town World Heritage Site In From Palermo To Penang: A Journey Into Political Anthropology by Fracois, R and Andrea, LIT Verlag GmbH \& Ko: Germany, pp. 283-296, 2010.

[19] Tuan, Y.F., Topophilia: A Study of Environmental Perception, Attitudes and Values, Prentice-Hall: New Jersey, 1974.

[20] Appleyard, D., The Conservation Of European Cities. The MIT Press: London, 1979.

[21] Lowenthal, D., Possessed by The Past: The Heritage Crusade and Spoils of History, Free Press: London, 1996.

[22] Rapport, A., The Meaning of Built Environment: A Nonverbal Communication Approach, Sage Publications: London, 1982.

[23] Wan Hashimah, W.I., Users Perception On The Heritage Value Of The Old Shophouses In The Historic City of Malacca, PhD. Thesis: UTM, 2009.

[24] Hasanuddin, L, Perception of Urban Landmarks in Kula Lumpur Between Designers, Non-designers and Laypublic. Fast Publication, 2003.

[25] Vahid, A, Hero, F, Adi, I et al., A Theoretical Base For Urban Morphology: Practical Way To Achieve The City Character, Journal of Social Sciences and Humanities, Vol. 4, No. 1, pp. 30-39, 2009.

[26] Norsidah, U., Place Attachment and users' perception of Kuala Lumpur City Centre, PhD. Thesis: UPM, 2007. 